\title{
The ANAlysis OF DYSCALCULIA STUDENTS LEARNING DIFFICULTY IN InClusive Education OF Primary SCHOOL LEVEL IN TASIKMAlaya
}

\author{
Nani Ratnaningsih ${ }^{1)}$, Ebih Abdul Rachim Arhasy ${ }^{2)}$, Edi Hidayat ${ }^{3)}$ \\ ${ }^{1)}$ Universitas Siliwangi, Tasikmalaya, Indonesia \\ E-mail: naniratnaningsih@unsil.ac.id \\ ${ }^{2)}$ Universitas Siliwangi, Tasikmalaya, Indonesia \\ E-mail: ebiharhasy@unsil.ac.id \\ ${ }^{3)}$ Universitas Siliwangi, Tasikmalaya, Indonesia \\ E-mail: edihidayat@unsil.ac.id
}

\begin{abstract}
Inclusive education is a government program that is realized through an inclusive school program to help students with disabilities so that their formal education can be well served. The implementation of inclusive education in Tasikmalaya City and District is less encouraging, various plans for implementing inclusive education need to be taken seriously. The purpose of this study: studying, analyzing, and describing the learning difficulties of dyscalculia students; discuss the challenges or learning process in inclusive schools for dyscalculia students. The method used in this study is descriptive qualitative and think aloud was carried out at 4 inclusive schools in Tasikmalaya namely SDN Manggungjaya 1, SDN Sukasirna, SDN Cibungkul and SDN Tanjung 2. The subjects in this study were principals, class teachers in inclusive schools, and dyscalculia students in grades 4, 5 and 6 of each. The methods used in this study were descriptive qualitative and think aloud. The instruments used the researchers themselves and questionnaires. The data were collected using observation, exploration, and interviews, all data obtained analyzed then described narratively. Based on the results of data analysis concluded: dyscalculia students in grades 4, 5 and 6 still have difficulty in reading and counting operations in numbers up to 50, do not understand negative integers. Just learning to study is still very difficult to condition, teachers who often teach dyscalculia students with their own learning styles. Learning is still held by the class teacher when the teacher comes from the Special Needs School. Ideally, at least two students with disabilities, provided by teachers who have a special education background.
\end{abstract}

Keywords: learning difficulty; dyscalculia; inclusive education

\section{INTRODUCTION}

Mathematics is a subject that is difficult to be understood and feared by almost every student, in connection with this, (Bisamandiri, 2014) suggests several cases where elementary students have difficulty learning mathematics, especially in understanding arithmetic concepts. Learning difficulties are not because IQ is below average but many factors cause it such as failure to understand, boring learning, and genetic factors. Students who have difficulty understanding arithmetic concepts are classified as having disabilities in dyscalculia. Students with dyscalculia must be treated early at the beginning of their education, although dyscalculia disorders are usually unconscious and difficult to be detected earlier (Rajaie, Allahvirdiyani, Khalili, \&
Sadeghi, 2011). Until now, students who have dyscalculia had less attention, even though every Indonesian had the same right to get an education, no exception. This is guaranteed in article 5 paragraph 1 of law number 20 of 2003 that every citizen has the same right to obtain qualified education. One of the government efforts to deal with dyscalculia disability provides a policy for the enactment of inclusive education (Kadir, 2015), but its implementation has not been optimal, due to the lack of special teachers who handle students with disabilities. An inclusive school is an ordinary or public school but accepts students with disabilities (Tan, Lambert, Padilla, \& Wieman, 2018), as according to (Yada \& Savolainen, 2017; Yada, Tolvanen, \& Savolainen, 2018) argues that inclusive education integrates students with disabilities with normal students (Le Fanu, 
2013; $\mathrm{Mu}, \mathrm{Hu}, \&$ Wang, 2017). Such as the Regency and City Government of Tasikmalaya launched 6 inclusive schools namely: SD Cibungkul Indihiang, SD Tanjung 2 Kawalu, SD Cibatu IV Sariwangi, SD Mangunreja 1, SD Sumelap 1 Mugarsari, and SD Karanglayung. Paying attention to these problems needs to be dealt with seriously, therefore it is very important to conduct research to explore and analyze the learning difficulties of students with dyscalculia type in order to provide input to the government for more serious treatment.

In general, for the children experiencing learning disorders occurs in elementary school age, learning disorders include the ability to obtain, store, or use special skills or information widely, resulting from a lack of attention, memory, or consideration and affect academic performance. There are 3 types of learning disorders: reading disorders (dyslexia), writing expression disorders (dysgraphia), and mathematical disorders (dyscalculia) (Santrok, 2012). Dyslexia, dysgraphia, and dyscalculia are three forms of learning difficulties experienced by children (Moreau, Wilson, McKay, Nihill, \& Waldie, 2018; Wang, Tasi, \& Yang, 2012). These three parts that are most difficult to recognize are dyscalculia. Students who experience learning disorders in mathematics are called dyscalculia disabilities or difficulty math. Dyscalculia students have difficulty understanding mathematical processes, this is usually characterized by the emergence of learning difficulties and working on tasks involving numbers or mathematical symbols. The characteristics of dyscalculia students presented on the website of Indonesian are as follows:

- The process of vision or visual weakness and problems with spatial (the ability to understand building space). In addition, it is difficult to enter the numbers in the right column.

- Difficulties in sorting, for example when asked to say a sequence of numbers. Confusion determines the left and right sides, as well as the disorientation of time (confused between the past and the future).

- Confused about distinguishing two numbers with almost the same shape, for example, numbers 7 and 9 , or numbers 3 and 8.

- Difficulty in understanding the concepts of time and direction, as a result often come late to school or to an event.

- Wrong in remembering or calling back the name of the person.

- Give a changeable answer (inconsistent) when given a question of addition, subtraction, multiplication, or division

- Difficulty in reading numbers on hours, or in determining locations such as the location of a city, road, and so on.

- Poor body coordination, for example, when following dancing movements.

Various problems were obtained through preliminary studies to inclusive schools where there were students with disabilities of the type of dyscalculia (De Visscher \& Noël, 2013; Zerafa, 2015), the service to students of dyscalculia had not run optimally, thus students of dyscalculia had not been well looked after. In addition, in some inclusive schools, there are no special teachers to handle dyscalculia students. The problem in this study focused on exploring the behaviors and learning difficulties of students with dyscalculia type disabilities in inclusive schools, as well as their solutions to learning so that students with disabilities can get the education they should. Research like this has not been studied much, especially in Tasikmalaya that no one has researched it. Paying attention to this problem needs to be addressed immediately, therefore the researcher conducted a study of the learning difficulties of students with disabilities type dyscalculia on inclusive education in Tasikmalaya City and Regency.

\section{RESEARCH METHODS}

The method used in this study is descriptive qualitative and think aloud was conducted in 4 Tasikmalaya inclusive schools, namely Manggungjaya 1 Elementary School, Sukasirna Elementary School, Cibungkul Elementary School and SDN Tanjung 2. The inclusive school taking was based on the direction of the Tasikmalaya District and Tasikmalaya District education, namely the two schools taken from Tasikmalaya District and Tasikmalaya City in two different zones. The subjects in this study were a principal from each inclusive school, grade 4, 5, 6 teachers and dyscalculia students in grades 4, 5 and 6 from each inclusive school as can be seen in Table I.

TABLE I

RESEARCH SUBJECT

\begin{tabular}{llll}
\hline No & Place & Inclusive School & $\begin{array}{l}\text { Dyscalculia } \\
\text { Students }\end{array}$ \\
\hline 1 & Tasikmalaya & SDN & 3 \\
& Regency & $\begin{array}{l}\text { Manggungjaya 1 } \\
\text { SDN Sukasirna }\end{array}$ & 6 \\
2 & Tasikmalaya & SDN Cibungkul & 6 \\
& City & SDN Tanjung 2 & 6 \\
Total & & & 21 \\
\hline
\end{tabular}

The instruments used were the researchers themselves and questionnaires. The study began with interviews with principals, teachers in grades 4, 5 and 6 and filled out questionnaires. Furthermore, observations were done to class 4,5 , and 6 during the learning process to find out more clearly about the behavior of dyscalculia students, then on different days, a test of counting was conducted using aloud thinking. Researchers along with students reading out math test questions include the operations of addition, multiplication, subtraction, and division, and sort numbers, then students answer them while explaining what is written by the direction of the researcher. This way, at the same time, will reveal students learning difficulties until saturated data is obtained which can be seen from how to answer students. All data obtained analyzed then described narratively. 


\section{RESULTS AND DISCUSSION}

This research was conducted at the Tasikmalaya District and City inclusive schools, namely in Manggungjaya 1 Elementary School, Sukasirna Elementary School, Cibungkul Elementary School, and Tanjung 2 Elementary School in Tasikmalaya City. Observations to the research schools and conducting interviews with principals and teachers, the researchers argue that how difficult it is to provide services to students with disabilities whose placement is not a special class but mingles with normal students. This is because there are no special teachers who have special education backgrounds, while in Tasikmalaya City and Regency elementary schools the teachers are still classroom teachers. Those are the condition of problems that occur in almost every inclusive school. The results of interviews with principals and teachers in inclusive schools that are the object of research are summarized in Table 2.

TABLE 2

INTERVIEW RESULT

\begin{tabular}{|c|c|c|}
\hline No & School & Interview Result \\
\hline 1 & $\begin{array}{l}\text { SD } \\
\text { Manggungjaya } 1\end{array}$ & $\begin{array}{l}\text { - There are } 3 \text { students with disabilities } \\
\text { that have a variety of disadvantages. } \\
\text { - There is no special teacher who } \\
\text { handles disability students, still a } \\
\text { classroom teacher. } \\
\text { - Because students with disabilities in } \\
\text { their classes are united with normal } \\
\text { students, they are very overwhelmed } \\
\text { in providing services in the learning } \\
\text { process. } \\
\text { - Sometimes there are teachers who } \\
\text { help from the SLB but not } \\
\text { continuously only at any time when } \\
\text { asked to come. }\end{array}$ \\
\hline 2 & SDN Sukasirna & $\begin{array}{l}\text { - There are } 6 \text { disability students. } \\
\text { - Learning is still a classroom teacher, } \\
\text { there is no special teacher yet. }\end{array}$ \\
\hline
\end{tabular}

- At any time there are teachers coming from the nearest special needs school when asked for help

3 SDN Cibungkul
- It was announced as an inclusive school since 2003 but has only been running for 2 years with teacher training.

- Disability students as many as 36 people with various deficiencies: hyperactivity, autism, physically disabled, spread from class 1 to grade 6.

- There are no special teachers who have special education, all are served by class teachers who mingle with normal students.

- Not all class teachers have participated in the training, only a few teachers have been involved, thus providing services to students with disabilities alone.

- Students with disabilities come from various regions: around the school, outside the sub-district, and even from outside the city.

- In the learning process, students with disabilities should be given more or special attention compared to normal students.

- Disability students just want to socialize with their friends is very difficult, especially for understanding material, especially numeracy in mathematics.

- There is already a teacher who has been trained to handle disability students and has become a resource person for training.

- There are no teachers who help from Special Needs School, but like to come to the nearest school to consult.

$4 \quad$ SDN Tanjung 2

- Special Needs students are 6 people with various shortcomings.

- There is already one teacher who has a special education background but still has difficulty in providing service to the learning process because students with disabilities are at different levels of the class. After all, the teacher is a class teacher, ideally, if the service to students with disabilities is to a maximum of at least there must be 6 teachers specifically dealing with students with disabilities.

- There were times when the teacher from the nearest special needs school came to help when asked for help because the special needs teachers were very overwhelmed to provide services at his school.

- Some teachers were involved in training.

Noting the results of the interview presented in the table, as well as the results of observations of researchers entering the classroom during the learning process, how complex the problems experienced by inclusive schools and their teachers in providing services to students with disabilities in their respective schools. Each school has relatively similar problems, so it requires serious handling and real solutions in accordance with the problems in their respective schools. These problems were obtained from 4 inclusive schools, it seems that in other inclusive schools in Tasikmalaya City and Regency they have relatively the same problems. From the results of interviews with classroom teachers, information was obtained that at every inclusive school dyscalculia students experienced problems in multiplication, division, addition, subtraction, and sequencing of numbers. Students lack enthusiasm for learning in following mathematics learning, learning difficulties in children lack concentration and students need assistance from the teacher (Ametepee \& Anastasiou, 2015).

Furthermore, the researchers conducted observations during the learning process to grades 4,5 and 6 in each 
school, how difficult it is for a teacher to carry out the learning process on inclusive schools because in one class there are normal students and students with disabilities. The problem is very complex, which cannot be solved alone because one class has 35 students consisting of ordinary students and disabilities (Maryam, Mahnaz, \& Hasan, 2011). Normal students can learn well, easily directed from the beginning to the end. Whereas dyscalculia students only for learning are difficult to be directed, engrossed in their own world. Some are silent every day they never write, just come to school. There were those who separated themselves sitting in front of the teacher desk, there was something that disturbed his friend, constantly not writing, especially working on the questions (Peard, 2010).

To explore the learning difficulties of students with dyscalculia, then take a test with a thinking technique, namely students answer questions as explained and researchers observe nearby. The questions tested to class 4 include the problem of counting operations, multiplication, subtraction, division, sorting of numbers less than 25; and less than 50 for class 5; and simple story questions for class 6. Presents the results of exploration and aloud thinking as can be seen in Tabel 3 .

TABLE 3

The DifFiculties OF DYSCALCULIA STUDENTS

\begin{tabular}{|c|c|c|}
\hline School & Class & Learning Difficulties \\
\hline \multirow[t]{3}{*}{$\begin{array}{l}\text { SD } \\
\text { Manggungjaya } \\
1\end{array}$} & 4 & $\begin{array}{l}\text { - Do not understand the addition, } \\
\text { multiplication, subtraction and } \\
\text { division operations of less than } 25 \\
\text { - Unable to sort numbers } \\
\text { - Do not understand the sign> and < }\end{array}$ \\
\hline & 5 & $\begin{array}{l}\text { - Having less understanding of the } \\
\text { multiplication, subtraction and } \\
\text { division operations of less than } 50 \\
\text { - Do not understand the sign> and < }\end{array}$ \\
\hline & 6 & $\begin{array}{l}\text { - It is hard to understand the story } \\
\text { question } \\
\text { - Difficult to change simple story } \\
\text { questions into mathematical symbols }\end{array}$ \\
\hline \multirow[t]{2}{*}{ SD Sukasirna } & 4 & $\begin{array}{l}\text { - Do not understand the addition, } \\
\text { multiplication, subtraction and } \\
\text { division operations of less than } 25 \\
\text { - Less ability to sort numbers } \\
\text { - Lack of understanding the sign> and } \\
<\end{array}$ \\
\hline & 5 & $\begin{array}{l}\text { - Difficult to do multiplication, } \\
\text { subtraction, and division operations } \\
\text { are less than } 50 \\
\text { - Lack of understanding the sign }>\text { and } \\
\text { - Do not understand the story question } \\
\text { - Difficulty changing simple story } \\
\text { questions into mathematical symbols }\end{array}$ \\
\hline \multirow[t]{2}{*}{ SD Cibungkul } & 4 & $\begin{array}{l}\text { - Less ability in understanding } \\
\text { multiplication operations, } \\
\text { subtraction, and division less than } 25 \\
\text { - Lack of understanding in sorting } \\
\text { numbers } \\
\text { - Do not understand the sign }>\text { and < }\end{array}$ \\
\hline & 5 & $\begin{array}{l}\text { - Lack in } \quad \begin{array}{c}\text { understanding } \\
\text { multiplication, }\end{array} \text { subtraction and }\end{array}$ \\
\hline
\end{tabular}

division operations of less than 50

- Lack in understanding the sign> and $<$

- Less understanding of the story question

- Less able to change simple story questions into mathematical symbols

SD Tanjung 24 - Less understanding multiplication operations, subtraction, and division less than 25

- Lack of understanding the sign> and $<$

5 - Less ability of multiplication, subtraction and division operations of less than 50

- Lack of understanding the sign> and $<$

6 - Less understanding of the story question

- Less able to change simple story questions into mathematical symbols

Based on Table 2, it can be concluded that dyscalculia students in grades 4 and 5 still have difficulties, in addition, multiplication, subtraction, sort numbers from the smallest to the largest or vice versa, difficulty in understanding mathematical symbols $>$ and $<$. Furthermore, class 6 dyscalculia students are less able to understand story problems, the difficulty in changing story problems into mathematical symbols. This is in accordance with the opinion of (Abdurrahman, 2010) which states that common mistakes made by children with learning difficulties are (1) lack of understanding of symbols, (2) place values, (3) use of erroneous processes, (4) calculations, (5) difficulties in language and reading.

Class 4 of dyscalculia students are able to calculate addition and subtraction less than 25 if using finger aids or other concrete objects and by repetition, because they are easy to forget, but still have difficulties in multiplication and distribution operations even by using fingers and concrete objects. Likewise for students in grade 5 for the calculation operations of less than 50 still experience difficulties in the division and multiplication operations. For students with dyscalculia grades 4 and 5 there are still difficulties in using symbols $>$ and <. Class 6 dyscalculia students have not been able to understand the problem of the story and turn it into a symbol or language of mathematics, he is able to understand after being helped read and then demonstrated using concrete media. Thus it can be concluded that students with dyscalculia grades 4 through 6 will be able to count or understand story problems when assisted to be read, demonstrated with the help of concrete objects. In accordance with opinion from (Purohit \& Margaj, 2012) which states that the difficulties of dyscalculia students are (1) counting, (2) visual-auditory, (3) computing skills, (4) language. Problems occur in dyscalculia students because of a disruption in the ability of the brain to receive, process, analyze and store information. According to (Geary, 2004), learning disabilities can result from deficits in the ability to 
represent or process information in one or all of the many mathematical domains (geometry), or in one or a set of individual competencies in each concept.

Looking at all the problems found in inclusive schools, there needs to be a solution so that inclusive education programs through inclusive schools can be handled well and seriously. This is because disability students have the right to receive proper education like other normal students. Some of the solutions offered are related to the learning process of dealing with dyscalculia students:

- Every school must have a teacher who handles special students with disabilities in which there are students with dyscalculia.

- The teacher directs students with patience, painstaking, and more attention to dyscalculia students compared to other normal students.

- The teacher must have a positive attitude, be patient and full of love, apply it warmly, friendly, and pleasant with the aim that students can learn more pleasantly.

- The teacher carries out a varied learning process so that students with disabilities are able to follow.

- Students with disabilities must be given an understanding many times, so they can understand it, or if they may be given additional hours to practice so as not to miss the normal friends.

- The teacher gives rewards if students dare to work on the problem, the reward does not always have to be material may be flattery and praise.

- In evaluating there is a difference between students with disabilities and normal students, meaning different ways, maybe interviews or oral tests.

- Providing gradual and continuous math problem training.

- The teacher begs parents to help study at home.

It is not easy to deal with students with disability type dyscalculia, it requires seriousness from all parties such as the government through its policies whose implementation must always be monitored, complemented by needs such as the teacher who handles it; school, teacher and headmaster; and parents who must be a solid and caring team.

\section{CONCLUSIONS}

Qualitative data analysis results obtained through interviews and questionnaires to school principals, teachers in grades 4, 5, and 6 at school, through direct observation to the class during the learning process, supported by the results of exploration and interviews with dyscalculia students when answering questions mathematical counting given through the think aloud method, obtained several conclusions that: (1) the implementation of inclusive education through inclusive schools has not gone well, there are still many shortcomings in its implementation, (2) the government is still not serious in handling it, (3) the absence of special teachers who handle disability students, (3) teachers have not provided maximum service to students with disability, this is seen from disability students left alone during the learning process without special services, because it is not easy to provide individual services for students divided by normal students and disabilities, (4) students with disabilities type dyscalculia grades 4 and 5 have learning difficulties in addition counting, subtraction, multiplication, division, sort numbers from the smallest to the largest or vice versa, using punctuation $>$ and <, (5) students with disabilities type dyscalculia grade 6 having difficulty learning in understanding story problems and turning them into mathematical symbols, (7) solutions in learning especially in mathematics learning, it takes care of teachers and parents, teachers provide services must be wholehearted, patient, and spend hours giving training repeatedly and continuously, so parents must help learn their children at home.

\section{ACKNOWLEDGMENT}

Thank you to his Excellency The Rector and Vice-Rectors, The Dean of the Teaching and Education Faculty, The chairman of the Siliwangi University P2M-PMP Institute who has facilitated and funded internal research programs. Also to the principal, teachers, and students at the research site, who have helped researchers from beginning to end. Hopefully, all of their assistance will be rewarded by Allah SWT.

\section{REFERENCES}

Abdurrahman, M. (2010). Pendidikan bagi anak berkesulitan belajar. Jakarta, Indonesia: Rineka Cipta.

Ametepee, L. K., \& Anastasiou, D. (2015). Special and inclusive education in Ghana: Status and progress, challenges and implications. International Journal of Educational Development, 41, 143-152. https://doi.org/10.1016/j.ijedudev.2015.02.007

Bisamandiri. (2014). Pembelajaran bagi anak berkebutuhan khusus diskalkulia. Retrieved March 1, 2019, from https://bisamandiri.com/blog/2014/11/pembelajaranbagi-anak-berkebutuhan-khusus-diskalkulia/

De Visscher, A., \& Noël, M. P. (2013). A case study of arithmetic facts dyscalculia caused by a hypersensitivity-to-interference in memory. Cortex, 49(1), https://doi.org/10.1016/j.cortex.2012.01.003

Geary, D. C. (2004). Mathematics and learning disabilities. Journal of Learning Disabilities, 37(1), 4-15. https://doi.org/https://doi.org/10.1177/0022219404037 0010201

Kadir, A. (2015). Penyelenggaraan Sekolah Inklusi di Indonesia. Pendidikan Agama Islam, 03(01), 17-22. https://doi.org/https://doi.org/10.15642/jpai.2015.3.1.1 $-22$

Le Fanu, G. (2013). The inclusion of inclusive education in international development: Lessons from Papua New Guinea. International Journal of Educational Development, 33(2), 139-148. https://doi.org/10.1016/j.ijedudev.2012.03.006

Maryam, A., Mahnaz, E., \& Hasan, A. (2011). Comparing the impact of number sense on mathematics 
achievement in both dyscalculia and normal students. Procedia - Social and Behavioral Sciences, 28, 5-9. https://doi.org/10.1016/j.sbspro.2011.11.002

Moreau, D., Wilson, A. J., McKay, N. S., Nihill, K., \& Waldie, K. E. (2018). No evidence for systematic white matter correlates of dyslexia and dyscalculia. NeuroImage: $\quad$ Clinical, $\quad 18, \quad 356-366$. https://doi.org/10.1016/j.nicl.2018.02.004

Mu, G. M., Hu, Y., \& Wang, Y. (2017). Building resilience of students with disabilities in China: The role of inclusive education teachers. Teaching and Teacher Education, 67, 125-134. https://doi.org/10.1016/j.tate.2017.06.004

Peard, R. (2010). Dyscalculia: What is its prevalence? Research evidence from case studies. Procedia Social and Behavioral Sciences, 8(5), 106-113. https://doi.org/10.1016/j.sbspro.2010.12.015

Purohit, S., \& Margaj, M. S. (2012). Analysis and detection of dyscalculia at early age using computer assisted friendly tests [ CrAFT ]. International Journal of Emerging Technology and Advanced Engineering, 2(12), 289-295. Retrieved from https://ijetae.com/index.html

Rajaie, H., Allahvirdiyani, K., Khalili, A., \& Sadeghi, A. (2011). Effect of teaching attention to the mathematic performance of the students with Dyscalculia in the third and fourth grade of elementary school. Procedia - Social and Behavioral Sciences, 15, 3024-3026. https://doi.org/10.1016/j.sbspro.2011.04.236
Santrok, J. W. (2012). Life-span development. (B. Widyasinta, Trans.) (13th ed.). USA: McGraw-Hill.

Tan, P., Lambert, R., Padilla, A., \& Wieman, R. (2018). A disability studies in mathematics education review of intellectual disabilities: Directions for future inquiry and practice. Journal of Mathematical Behavior, (July), 1-13. https://doi.org/10.1016/j.jmathb.2018.09.001

Wang, L. C., Tasi, H. J., \& Yang, H. M. (2012). Cognitive inhibition in students with and without dyslexia and dyscalculia. Research in Developmental Disabilities, 33(5), 1453-1461. https://doi.org/10.1016/j.ridd.2012.03.019

Yada, A., \& Savolainen, H. (2017). Japanese in-service teachers' attitudes toward inclusive education and selfefficacy for inclusive practices. Teaching and Teacher Education, 64, 222-229. https://doi.org/10.1016/j.tate.2017.02.005

Yada, A., Tolvanen, A., \& Savolainen, H. (2018). Teachers' attitudes and self-efficacy on implementing inclusive education in Japan and Finland: A comparative study using multi-group structural equation modelling. Teaching and Teacher Education, 75, 343-355. https://doi.org/10.1016/j.tate.2018.07.011

Zerafa, E. (2015). Helping Children with Dyscalculia: A Teaching Programme with three Primary School Children. Procedia - Social and Behavioral Sciences, 191(1072425), 1178-1182. https://doi.org/10.1016/j.sbspro.2015.04.516 